\title{
Hypertension Guidelines: Timely New Initiatives from East Asia
}

\author{
John Chalmers
}

The George Institute for Global Health, The University of Sydney and Royal Prince Alfred Hospital, Sydney, N.S.W., Australia

This issue of Pulse brings together reviews of new or pending guidelines for the management of hypertension from China, Japan, Korea and Taiwan, covering the vast populations of East Asia [1-9]. This is a most timely and welcome initiative for many reasons. The first is that Asia is experiencing the 'second-wave epidemic', as it makes the transition from infectious diseases to chronic, non-communicable diseases, especially cardiovascular disease, overweight and diabetes. The second is that the burden of cardiovascular disease is quite different in Far East Asia, compared to western societies where stroke or cerebrovascular disease is much more common than coronary disease. Furthermore, there is a much higher incidence of haemorrhagic stroke in these nations, with a more direct and steeper relationship to high blood pressure, compared to western nations where ischaemic stroke predominates. The third reason is that the last few years have seen a break in the previous consensus amongst western guidelines, which had previously recommended a target blood pressure of $\leq 140 / 90 \mathrm{~mm} \mathrm{Hg}$ for most people with hypertension but $<130 / 80 \mathrm{~mm} \mathrm{Hg}$ for high-risk groups with previous vascular disease, diabetes or chronic kidney disease [10-12].

More recently, many opinion leaders have raised doubts concerning these target blood pressures, reflecting numerous reports of J curves observed with lower achieved blood pressures in post hoc analyses of major trials [13], and this has been reflected in recent guidelines from Europe and the United States [14-18]. These guidelines broadly agree that a target of $<140 / 90 \mathrm{~mm}$ Hg remains appropriate for uncomplicated patients with hypertension who are below the age of 60 years, but the American guidelines, as reported by panel members from JNC8 and by the science advisory issued by AHA/ACC/CDCP $[15,16]$, actually recommend raising this target to $<150 / 90 \mathrm{~mm} \mathrm{Hg}$ for patients over the age of 60 years, drawing a dissenting report from some members appointed to JNC8 [19]. All these guidelines agree with the goal of $<150 / 90$ or $140-150 / 90 \mathrm{~mm}$ Hg for patients over the age of 80 years, reflecting the HYVET (HYpertension in the Very Elderly Trial) trial [20]. However, most guidelines have removed their earlier recommendations that the target should be $<130 / 80 \mathrm{~mm} \mathrm{Hg}$ in high-risk groups, apart from the ESH/ESC guidelines, which maintain a diastolic blood pressure goal of $<85 \mathrm{~mm}$ 
$\mathrm{Hg}$ for patients with diabetes [18]. The other bone of contention regards recommendations for first-line drug classes, where the European guidelines retain 5 main groups [ACEI, ARB, $\mathrm{CCB}$, diuretics and beta blockers (BB)], while all the others relegate $\mathrm{BB}$ to second line for special situations such as for patients with coronary heart disease. The NICE guidelines also differ, in that they require ambulatory blood pressure monitoring to confirm the diagnosis of hypertension before the initiation of drug treatment [17].

In this context, the time is clearly ripe for a consolidation of recommendations for the management of hypertension in the major populations of Asia. The four sets of guidelines that are reviewed in this issue of Pulse clearly set the pace and bring their own unique perspectives to bear upon the subject. It is not surprising that, as for the western guidelines, there are some clear differences among their many recommendations. But all are thoughtful, well researched and balanced. One area of difference, compared to the recent western guidelines, is that all four of these Asian guidelines recommend more stringent blood pressure targets for some groups of patients, albeit with some variation amongst these. The Japanese guidelines recommend a retention of the target of $<130 / 80 \mathrm{~mm} \mathrm{Hg}$ for patients with diabetes or chronic kidney disease and albuminuria $[3,7]$, and the Taiwan guidelines advocate this same target for patients with diabetes and proteinuric renal disease, and additionally for those with coronary disease and those receiving antithrombotic drugs for stroke prevention $[5,9]$. The Korean guidelines recommend tighter targets for high-risk patients, specifically $<140 / 85 \mathrm{~mm}$ $\mathrm{Hg}$ for patients with diabetes and $<130 / 80 \mathrm{~mm} \mathrm{Hg}$ for those with chronic renal disease and prominent albuminuria [4, 8]. The Chinese guidelines from 2011 recommend a target of $<130 / 80 \mathrm{~mm} \mathrm{Hg}$ for patients with diabetes, chronic kidney disease, or coronary disease, but not for those with stroke $[2,6]$. These Asian guidelines also focus on target blood pressures for the elderly, and all four recommend a target of $<150 / 90 \mathrm{~mm} \mathrm{Hg}$ for older adults, but they differ in the ages at which this applies. For the Chinese guidelines, this target applies for subjects over the age of 65 years, for the Japanese it applies for 'late-phase elderly'. The Korean guidelines recommend a target systolic blood pressure between 140 and $150 \mathrm{~mm} \mathrm{Hg}$ in patients over the age of 65 years, while the Taiwan guidelines advocate a target blood pressure of $<150 / 90 \mathrm{~mm} \mathrm{Hg}$ for elderly subjects over the age of 80 years.

Finally, there is much agreement in the recommendations for drug treatment among the guidelines, with those from China, Korea and Taiwan recommending 5 groups of first-line drugs (ACEI, ARB, CCB, diuretics and BB); the Japanese guidelines relegate BB to second line. All four guidelines recommend combination therapy, including the use of single-pill combinations, particularly in patients with very high pressures or with resistant hypertension. And all recommend the primary use of clinic blood pressures, with considerable focus on the supplementary use of home blood pressures and ambulatory blood pressure monitoring.

In summary, these four sets of guidelines [2-9] make a very timely and substantial contribution to the management of hypertension in the vast populations of Asia that are increasingly burdened by hypertension, metabolic disorders and cardiovascular disease. The four guidelines apply to populations with great similarities in the characteristics of their hypertension and their cardiovascular disease burden. As such, it is tempting to think that this initiative foreshadows a joint effort to come together as a first step in producing a set of 'Asian Guidelines'. This might well start with a set of 'Guidelines for the Management of Hypertension in East Asia' in view of the great similarities in these populations and the work already achieved by the four separate sets of guidelines represented here. It might also be helpful to enlist the support and participation of the Asian-Pacific Society of Hypertension and the Asian-Pacific Society of Cardiology. Whatever the route forward might be, these first steps, brought together in this issue of Pulse, represent a major contribution to improving the control of hypertension - the world's greatest killer - across the many billions of people who live in this part of the world. 


\section{Disclosure Statement}

J.C. has received research grants, honoraria and travel support from Servier as Principal Investigator for the ADVANCE trial and ADVANCE-ON post-trial follow-up study.

\section{References}

$>1$

2

$>3$

$>4$

$>5$

$>6$

$>7$

for the management of hypertension (in Chinese).Zhonghua Xin Xue Guan Bing Za Zhi 2011;39:579-615.
Shimada K, Shimosawa T, Suzuki H, Tamura K, Tanahashi N, Tsuchihashi T, Uchiyama M, Ueda S, Umemura S; Japanese Society of Hypertension Committee for Guidelines for the Management of Hypertension: The Japanese Society of Hypertension guidelines for the management of hypertension (JSH 2014). Hypertens Res 2014;37: 253-387.

-8 Shin J, Park JB, Kim K, Kim JH, Yang DH, Pyun WB, Kim YG, Kim GH, et al: 2013 Korean Society of Hypertension guidelines for the management of hypertension. Part I - epidemiology and diagnosis of hypertension. Clin Hypertens 2015;21:1.

-9 Chiang CE, Wang TD, Ueng KC, Lin TH, Yeh HI, Chen CY, Wu YJ, Tsai WC, Chao TH, Chen CH, Chu PH, Chao CL, Liu PY, Sung SH, Cheng HM, Wang KL, Li YH, Chiang FT, Chen JH, Chen WJ, Yeh SJ, Lin SJ: 2015 guidelines of the Taiwan Society of Cardiology and the Taiwan Hypertension Society for the management of hypertension. J Chin Med Assoc 2015;78:1-47.

10 World Health Organisation International Society of Hypertension Writing Group: 2003 World Health Organisation (WHO)/International Society of Hypertension (ISH) statement on management of hypertension. J Hypertens 2003;21:1983-1992.

$>11$ Chobanian AV, Bakris GL, Black HR, Chusman WC, Green LA, Izzo JL Jr, et al; National Heart, Lung, and Blood Institute Joint National Committee on Prevention, Detection, Evaluation, and Treatment of High Blood Pressure; National High Blood Pressure Education Program Coordinating Committee: The seventh report of the Joint National Committee on Prevention, Detection, Evaluation and Treatment of High Blood Pressure: the JNC 7 report. JAMA 2003;289:2560-2572.

-12 Mancia G, de Backer G, Dominiczak A, Cifkova R, Fagard R, Germano G, et al: 2007 guidelines for the management of arterial hypertension: the Task Force for the Management of Arterial Hypertension of the European Society of Hypertension (ESH) and the European Society of Cardiology (ESC). J Hypertens 2007;25:1105-1187.

$>13$ Chalmers J: Is a blood pressure target of <130/80 mm Hg still appropriate for high risk patients? Circulation 2011; 124:1700-1702.

14 Weber MA, Schiffrin EL, White WB, Mann S, Lindholm LH, Kenerson JG, Flack JM, Carter BL, Materson BJ, Ram CV, Cohen DL, Cadet JC, Jean-Charles RR, Taler S, Kountz D, Townsend R, Chalmers J, Ramirez AJ, Bakris GL, Wang J, Schutte AE, Bisognano JD, Touyz RM, Sica D, Harrap SB: Clinical Practice Guidelines for the Management of Hypertension in the Community. A statement by the American Society of Hypertension and the International Society of Hypertension. J Hypertens 2014;32:3-15.

15 James PA, Oparil S, Carter BL, Cushman WC, Dennison-Himmelfarb C, Handler J, Lackland DT, Lefevre ML, Mackenzie TD, Ogedebe 0, Smith SC Jr, Svetkey LP, Taler SJ, Townsend RR, Wright JT Jr, Narva AS, Ortiz E: 2014 evidencebased guidelines for the management of high blood pressure in adults: report from the panel members appointed to the eighth Joint National Committee (JNC 8). JAMA 2014;311:507-520.

-16 Go AS, Bauman M, King SM, Fonarow GC, Lawrence W, Williams KA, Sanchez E: An effective approach to high blood pressure control: a science advisory from the American Heart Association, the American College of Cardiology, and the Center for Disease Control and Prevention. J Am Coll Cardiol 2014;63:1230-1238.

17 National Institute for Health and Clinical Excellence: Hypertension: management of hypertension in adults in primary care 2011. https://www.nice.org.uk/guidance/cg127.

18 Mancia G, Fagard R, Narkiewicz K, Redon J, Zanchetti A, Böhm M, Christiaens T, Cifkova R, De Backer G, Dominiczak A, Galderisi M, Grobbee DE, Jaarsma T, Kirchhof P, Kjeldsen SE, Laurent S, Manolis AJ, Nilsson PM, Ruilope LM, Schmieder RE, Simes PA, Sleight P, Viigimaa M, Waeber B, Zannad F; Task Force Members: 2013 ESH/ESC Guidelines for the management of arterial hypertension: the Task Force for the management of arterial hypertension of the European Society of Hypertension (ESH) and of the European Society of Cardiology (ESC). J Hypertens 2013; 31:1281-1357.

19 Wright JT Jr, Fine LJ, Lackland DT, Ogedegbe G, Dennison Himmelfarb CR: Evidence supporting a systolic blood pressure goal of less than $150 \mathrm{~mm} \mathrm{Hg}$ in patients aged 60 years or older: the minority view. Ann Intern Med 2014; 160:499-503.

20 Beckett NS, Peters R, Fletcher AE, Staessen JA, Liu L, Dumitrascu D, Stoyanovsky V, Antikainen RL, Nikitin Y, Anderson C, Belhani A, Forette F, Rajkumar C, Thijs L, Banya W, Bulpitt CJ; HYVET Study Group: Treatment of hypertension in patients 80 years of age or older. N Engl J Med 2008;358:1887-1898. 